\title{
LINGUOCONFLICTOLOGY AND CONFLICTS IN RUSSIAN MEDIA (ANALYSIS OF DOUBLE CASE)
}

\author{
Elena S. Kara-Murza \\ Lomonosov Moscow State University, Moscow, Russia
}

\begin{abstract}
The article is devoted to linguoconflictology - a branch of Russian linguistics, which reveals the causes and consequences of confrontational interaction. The article describes the history of its formation in the framework of legal linguistics as one of the linguophilosophical foundations of judicial linguistic expertise. Linguoconflictology is addressed, first of all, to future and current linguists-experts and is intended to make them aware of the regularities of conflict communication, which is subject to judicial linguistic examination, and the conflict nature of the expert activity itself; and secondly, future and current employees of mass media - for the prevention of speech torts in them. The author's version of this science is described. The author reveals its basic concepts and shows the gradation from communicative failure to communicative conflict, which is characterized as normative-axiological and occurs when the norms of communication (naive-ethical, professional-ethical and legal) are violated. According to the author, it should be distinguished from speech conflict as a form of activity. Specific to this variant of linguoconflictology is the linguo-legal conflict. Its occurrence is caused by violation of legal requirements and prohibitions. The analysis algorithm developed by the author is demonstrated by the example of a double case - a conflict that began in the sports sphere as an injury in a stage football match, and continued in the media space of sports journalism as a communicative conflict and it almost escalated into a conflict linguolegal.

Key words: linguoconflictology, judicial linguistics, classification of conflicts, conflictogenes, linguolegal conflict, linguistic expertise.
\end{abstract}

Citation. Kara-Murza E.S. Linguoconflictology and Conflicts in Russian Media (Analysis of Double Case). Vestnik Volgogradskogo gosudarstvennogo universiteta. Seriya 2. Yazykoznanie [Science Journal of Volgograd State University. Linguistics], 2020, vol. 19, no. 1, pp. 18-27. (in Russian). DOI: https://doi.org/10.15688/ jvolsu2.2020.1.2

\section{ЛИНГВОКОНФЛИКТОЛОГИЯ И КОНФЛИКТЫ В РУССКОМ МЕДИАПРОСТРАНСТВЕ (АНАЛИЗ ДВОЙНОГО КЕЙСА)}

\author{
Елена Станиславовна Кара-Мурза \\ Московский государственный университет им. М.В. Ломоносова, г. Москва, Россия
}

\begin{abstract}
Аннотация. Статья посвящена лингвоконфликтологии - направлению российской лингвистики, изучающему причины и последствия конфронтационного общения. Охарактеризовано ее становление в рамках юрислингвистики как одной из лингвофилософских основ судебной лингвистической экспертизы. Описано авторское понимание объекта этого направления науки, раскрыты его основные понятия, представлена гра已ं дация разновидностей конфликтного поведения от коммуникативной неудачи до коммуникативного конфликта, который возникает при нарушении наивно-этических, профессионально-этических и юридических норм коммуникации и поэтому является нормативно-аксиологическим. Автором доказано, что этот вид конфликта отличается от речевого конфликта как формы деятельностного конфликта. Установлен специфический для лингвоконфликтологии конфликт - лингвоправовой, который возникает в результате нарушения законодательных требований и запретов. Проанализирован двойной кейс: конфликт, который начался в спортив(2) ной сфере, продолжился в медиапространстве спортивной журналистики и едва не перерос в конфликт
\end{abstract}


лингвоправовой. Продемонстрировано, что знания в области лингвоконфликтологии необходимы, во-первых, практикующим лингвистам-экспертам и будущим специалистам в этой области, поскольку позволяют им осознать закономерности конфликтного общения, которое подлежит судебной лингвистической экспертизе, и конфликтогенность самой экспертной деятельности; во-вторых, работникам массмедиа для профилактики речевых деликтов.

Ключевые слова: лингвоконфликтология, юрислингвистика, классификация конфликтов, конфликтогены, лингвоправовой конфликт, лингвистическая экспертиза.

Цитирование. Кара-Мурза Е. С. Лингвоконфликтология и конфликты в русском медиапространстве (анализ двойного кейса) // Вестник Волгоградского государственного университета. Серия 2, Языкознание. 2020. - T. 19, № 1. - C. 18-27. - DOI: https://doi.org/10.15688/jvolsu2.2020.1.2

\section{Введение}

В настоящее время в российской лингвистике сформировалось несколько направлений, которые связаны с изучением конфронтационного общения. Некоторые из них развиваются в когнитивно-коммуникативной парадигме, а некоторые имеют междисциплинарный характер: эколингвистика, юрислингвистика, речевая конфликтология, лингвоконфликтология. В центре внимания в данной публикации находится последняя из упомянутых наук - лингвоконфликтология (далее - ЛКЛ), ее основные понятия, проблематика, цели и задачи.

С начала 90-х г. XX в. в отечественной гуманитаристике, и прежде всего в философии и социологии, началось исследование конфликта как важного социального феномена. В это время в науке осваивались зарубежные концепции, разрабатывались собственные представления как в области общей конфликтологии, так и в сфере ее частных отраслей (педагогической, политической, юридической). В коммуникативной лингвистике еще с середины 80-х гг. прошлого века активизировалось изучение разных форм речевой агрессии, манипуляции, коммуникативных неудач и сбоев, и опора на достижения конфликтологии привели к осознанию конфликта как особого типа общения: он «подразумевает столкновение сторон, состояние противоборства партнеров в процессе коммуникации по поводу несовпадающих интересов, мнений, коммуникативных намерений, которые выявляются в ситуации общения. Речевой конфликт имеет место тогда, когда одна из сторон в ущерб другой сознательно и активно совершает речевые действия, которые могут выражаться соответствующими - негативными - средствами язы- ка и речи. $<\ldots>$ Эта противонаправленная интеракция и есть речевой конфликт» [Третьякова, 2010, с. 141].

Понятийный аппарат конфликтологии был адаптирован для нескольких речеведческих вариантов с разными названиями. Существует универсалистский, общий подход к речевым проблемам на материале повседневной речи и художественной литературы. Его название, предлагаемое и В.С. Третьяковой, отражено в вузовском учебнике Санкт-Петербургского государственного педагогического университета имени А.И. Герцена [Речевая конфликтология, 2008]. Применяется также частный подход, сформированный в работах профессора Н.Д. Голева в рамках его концепции юрислингвистики как лингвофилософской основы производства судебных лингвистических экспертиз [Голев, 2003] и получивший название «лингвистическая конфликтология / лингвоконфликтология». Считается, что данный подход наиболее близок юридической конфликтологии [Ворошилова, 2013].

Согласно дефиниции из словаря «Эффективное общение (базовые компетенции)», лингвистическая конфликтология - это «направление коммуникативной лингвистики, изучающее проблемы некооперативного, конфликтного общения». Ее понятийная система и инструментарий анализа «находятся в стадии формирования» [Голев, Обелюнас, 2014, с. 279]. Определено, что в центре данной дисциплины находится понятие речевого (в различной терминологии - языкового, коммуникативного) конфликта - «явления, маркирующего отрицательное поле коммуникативного взаимодействия» [Голев, Обелюнас, 2014, с. 279]. С середины 2000-х гг. лингвоконфликтология была разделом юрислингвистики как дисциплины специализации на филологическом факульте- 
те Алтайского государственного университета (г. Барнаул). С 2013 г. она преподается филологам-практикам как самостоятельный авторский курс. В аннотации к учебному пособию «Основы лингвоконфликтологии» сказано, что это «новая лингвистическая дисциплина прикладного цикла, возникшая на стыке языка и права. Ее формирование обусловлено рядом актуальных задач современной языковедческой и юрислингвистической теории и практики, призванных, с одной стороны, описать разнообразные речевые конфликты, возникающие в разных сферах деятельности человека говорящего и воспринимающего, а с другой - способствовать выработке приемлемых с позиций лингвистики и права норм и правил, направленных на решение вопросов юридизации речевых конфликтов» [Чернышова, 2017, с. 3]. С 2007 г. ее вариант читается в Институте судебных экспертиз Московской государственной юридической академии как пропедевтический курс [Кара-Мурза, 2010а].

Будущие лингвокриминалисты, изучая лингвоконфликтологию, постигают глубинные причины социальных конфликтов, квалифицируемых сторонами как речевые деликты, которые можно доказать или опровергнуть при помощи судебных экспертиз [Галяшина, 2017]. Они осознают позитивную социальную роль СМИ - «сторожевого пса демократии», в то время как руководители бизнеса и политики пытаются пресечь критические журналистские публикации через необоснованные иски о защите чести, достоинства и деловой репутации [Понятия чести..., 2004]. В компетенцию лингвокриминалистов должно входить также понимание того, что само правоприменение, включая производство лингвистических экспертиз, конфликтогенно и что в своей деятельности они обязаны противостоять возможному административному давлению, придерживаясь законодательного принципа независимости эксперта.

В настоящее время лингвоконфликтология как учебная дисциплина преподается во многих российских вузах (например, в Волгоградском государственном социально-педагогическом университете) [Декатова], преимущественно в магистратуре по профилю «лингвистическая экспертиза». Она институциализирована: в 2016 г. в Высшей школе эко- номики создана научно-учебная лаборатория лингвоконфликтологии, которой руководит специалист по языку Интернета профессор М.А. Кронгауз.

\section{Материал и методы исследования}

В общей конфликтологии применяется универсальная система описания конфликта, включающая 11 групп / пунктов: сущность конфликта, типология, структура, функиии, эволючия, генезис, динамика, информачия в конфликте, предупреждение, завершение конфликта, исследование и диагностика [Анцупов, Шипилов, 2000, с. 148]. М.А. Кронгауз в интервью «Российской газете» назвал эту систему архитектурой конфликта (Новоселова Е. Холивар не выдержит двоих // Российская газета. 2016. 1 сент. URL: https://rg.ru/2016/09/01/maksim-krongauzmezhgosudarstvennye-lingvisticheskie-bitvy-deloobychnoe.html). Исследовательские схемы модифицируются для разных коммуникативных ситуаций, см.: конфликт, предмет конфликта, объект конфликта, конфликтная ситуачия, стороны конфликта, границы конфликта, этапь конфликта, фазы конфликта, инцидент, конфликтогены, функиии конфликта [Чернышова, 2017, с. 14]. На основе предложенных учеными систем описания коммуникативного конфликта мы разработали собственную, которую продемонстрируем при анализе двойного кейса.

Отметим, что обычно термины «конфликт языковой / речевой / коммуникативный» используются недифференцированно. Мы предлагаем различать эти объекты, исходя из того, что общение является неотъемлемым компонентом практически всех взаимодействий, от бытовых до рабочих и досуговых, а речевая составляющая присутствует в любом типе конфликта как его форма или орудие. Так, конфликтные проявления можно считать конфликтами коммуникативными (а не речевыми), если: 1) технологические либо креативные аспекты коммуникации воспринимаются как ресурс, за который идет борьба интересов (как за федеральный эфир для политиков во время избирательной кампании); 2) в ходе общения были нарушены этические нормы профессиональной коммуникации (например, 
в пропагандистских ток-шоу); 3) были нарушены законодательные требования к медиакоммуникациям (см., например, законы «О СМИ», «О рекламе» и др.). Эти конфликты демонстрируют те же причины и те же типы, что и деятельностные, а именно: конфликты ресурсов, интересов, ценностей и норм.

Функционирование и/или восприятие языка в качестве ресурса относится прежде всего к коду и каналу коммуникации: это владение государственным или иностранным языком, распоряжение вещательными технологиями, их временем и пространством. Например, ограничения на распространение предвыборной агитации оппозиционных партий и политиков - это конфликт и политический (речевой в политической сфере), и коммуникативный (нарушение конвенций политической коммуникации или избирательного законодательства). Содержание информации тоже может восприниматься как конкурентный ресурс. Так, в СССР существовала цензура, был ограничен доступ к «неблагонадежной» литературе, для которой были устроены спецхраны; а в современной России минимизированы независимые массмедиа. Информация обладает идейной или духовной ценностью, которая оспаривается сторонами конфликта, и спор в диапазоне от научной полемики до религиозной дискуссии может «возгоняться» до конфликта. Ценность речевых произведений (от романов до товарных знаков) может описываться в терминах интеллектуальной собственности, по ч. IV ГК РФ они могут стать объектом плагиата.

Что касается медиаконфликтов, то формально они являются речевыми, сущностно коммуникативными, а содержательно - конфликтами интересов, ценностей и норм. Так, журналистика призвана формировать общественное мнение массовой аудитории, а не служить частным интересам политиков, чиновников или бизнесменов посредством «белого» или «черного» пиара либо интересам фирм-производителей посредством «серой» рекламы. При этом она регулируется и общим российским законодательством, и отраслевым законом. Поэтому журналистские выступления становятся постоянным источником конфликтов по ст. 4 ФЗ «О СМИ» о злоупотреблении свободой массовой информации или по ст. 282 УК РФ о разжигании межнациональной или социальной розни.

Объект лингвистической конфликтологии формируют коммуникативные конфликты, обладающие всеми характеристиками, которые обнаружены применительно к деятельностным: такой же причинностью, мотивировкой и субъектной структурой, такими же сюжетными поворотами и возможностями разрешения. Лингвоправовой конфликт (далее - ЛПК) является специфическим объектом ЛКЛ. Он определяется на основании содержательного критерия как аксиологический - конфликт ценностей и норм - при нарушении (настоящем или мнимом) некоторой правовой нормы как речеповеденческой. В этой же типологической нише расположены такие конфликты, как наивно-этический и профессионально-этический. По нашему мнению, лингвоправовой конфликт и языковое / речевое преступление это один и тот же феномен, рассматриваемый под разными названиями в разных дисциплинах: как лингвоправовой конфликт - в лингвоконфликтологии и в юрислингвистике; как языковое / речевое преступление - в лингвоэкспертологии. Кроме того, в нашей концепции делается акцент на градации некооперативного взаимодействия разных видов: от коммуникативной неудачи до коммуникативного / лингвоправового конфликта и речевого деликта, то есть к правонарушению и преступлению.

Поскольку лингвоправовой конфликт обладает двойственной природой, постольку основная схема его анализа взята нами из юридической конфликтологии и основана на различении его объективной и субъективной сторон. Конкретизируется она через структуру коммуникативной ситуации (в понимании Р.О. Якобсона), где все компоненты (адресант, адресат, сообщение, код, контакт, контекст) рассматриваются как конфликтогены. Вне зависимости от природы конфликтогена существенную роль в развитии любого конфликта играют когнитивные / интерпретативные механизмы [КараМурза, 2010б].

Предмет лингвоконфликтологии составляют речеповеденческие и текстовые показатели разной знаковой природы (словесные, визуальные). Для лингвоправового конфликта это выявленные в лингвоэкспертологии параметры, которые коррелируют с признаками со- 
става правонарушения или преступления, зафиксированными в диспозициях статей и в комментариях юристов. Материал ЛКЛ - конфликты, отображенные в таких источниках, как медиатексты, исковые заявления и «экстракты» лингвистических экспертиз.

Материалы для нашего исследования взяты из сетевых изданий; обстоятельства дела и должности фигурантов актуальны для описанной ситуации; тексты приведены в авторской редакции (см. развернутый вариант: [Кара-Мурза, 2011]).

\section{Результаты и обсуждение}

Анализ кейса многоэтапного конфликта с медийной составляющей описывается через следующие взаимодополнительные параметры: институииональность, профессионализм, нормативность, модус, материя, субъектность, хронотоп, масштаб, ресурcы, интересы участников, иенности, нормы, информационное воплощение. Рассмотрим их подробнее.

1. Институциональность (рече)деятельностной сферы анализируемой ситуации спорт, конкретнее - футбол.

29 августа 2011 г. на футбольном матче «Спартак» - «ЦСКА» (это был отборочный этап внутрироссийского цикла) нападающий «Спартака» бразильский легионер Веллитон, имеющий репутацию «жесткого» игрока, налетел на И. Акинфеева, голкипера одновременно «ЦСКА» и сборной России, в результате чего тот получил травму, которая вывела его на много месяцев из строя незадолго до международных игр. Спартаковец был наказан - дисквалифицирован на несколько матчей, но ситуация оставалась острой.

Деятельностная фаза данного конфликта на этом фактически закончилась, а началась спортивно-коммуникативная: в спортивных изданиях и на сетевых ресурсах руководители «Спартака» и «ЦСКА» (традиционно соперничающих) и их болельщики продолжали обсуждать этот инцидент; спектр мнений демонстрировал стилистическую рефлексию и конфликт интерпретаций.

2. Профессиональные проблемы (неэффективность управленческих решений, неоптимальное выступление спортсменов, недо- стижение результата) стали поводом для высказываний.

3. Нормативность игрового взаимодействия футболистов стала центром внимания участников ситуации и фокусом обсуждения.

4. Модус социальных интеракций - «игровой». В конфликтологии различаются такие понятия, как «сражение», «игра» и «дебаты». Спорт по своей сути - это игра и сублимация инстинктов, спортивные конфликты имеют характер игровых, которые, однако, могут обостриться до степени «военных действий», сопровождаться травмами и драками, что и имело место в рассматриваемом примере.

5. Конфликты бывают разной материальной природы: телесные и орудийные (драки, войны, спортивные соревнования, особенно командные, в том числе игры с мячом) - и могут иметь физические последствия (спортивные травмы).

6. Субъектный параметр связан непосредственно с участниками спортивного конфликта - нападающим и вратарем. Соучастниками конфликта здесь становятся игроки команд. В коммуникативном конфликте субъекты инициальной и ответной реплики - функционеры и спортсмены; в фазе медиаконфликта появляется медиааудитория, в том числе болельщики-блогеры. В подобных ситуациях важна субъектная роль эксперта - знатока, и в этом конфликте таких экспертов было много среди спортсменов.

29 августа 2011 г. на портале www.evrofootball.ru публикатор под никнеймом feodorff814966 собрал мнения по поводу обсуждаемой ситуации, авторы которых разошлись в оценке причин и характера столкновения футболистов. Генеральный директор «Спартака» и его главный тренер В. Карпин защищали своего игрока с психологической стороны:

Со стороны Веллитона однозначно злого умысла не было. То, что вратарь сборной выбыл на полгода, - это его проблемы. Что, медаль ему повесить? Не трогать теперь игроков сборной?

Известный арбитр С. Хусаинов (в тот момент уже пенсионер) в интервью «Советскому спорту» сказал:

Возможно, ЦСКА рисковал, выпуская на игру, как мне кажется, не совсем здорового Акин- 
феева. Армейцы должны были знать, в какой манере играет Веллитон. Он всегда идет до конца и не боится столкновений, которые могут привести к травме. Мне показалось, что он пошел на контакт, заведомо зная, что может нанести травму. Судьям нужно быть готовым к такому поведению бразильца и пресекать его действия на корню.

Бывший вратарь «Спартака»и «ЦСКА» Р. Нигматуллин не винил в случившемся только нападающего:

Бразилец в данном моменте смотрел на мяч, и, на мой взгляд, не хотел травмировать Акинфеева. Просто после столкновения Игорь неудачно приземлился, и колено не выдержало. Конечно, многие, наверное, скажут, что вратарь упал из-за контакта с нападающим, но форвард ведь тоже упал.

Что касается роли арбитра - институционального участника, который уполномочен квалифицировать проступок и назначать наказание, то она проявилась и на спортивном этапе данного кейса (отстранение игрока Веллитона), и на коммуникативном этапе (отстранение журналиста Д. Губерниева от комментирования футбольных матчей). Однако в данной публикации эти роли не рассматриваются.

Как показывает анализ материалов, конфликтогенными являются личностные свойства конфликтантов: их психофизические качества, включая командную или персональную несовместимость, и профессиональные навыки. Обозреватель газеты «Советский спорт» Е. Ловчев в одном из сетевых изданий на вопрос о том, почему тяжелая травма вратаря «ЦСКА» и сборной России И. Акинфеева и вся эта история обсуждается больше, чем новости сборной, ответил:

Значит, у нас сборная такая. $<\ldots .>$ Прочитал газеты, отклики футболистов-сборников и снова убедился, что там собрана компашка, которая оторвалась от жизни, считает себя исключительными. <...> А здесь все сошлось: дерби, вратарь сборной, накануне сборной... История раздута. Вопрос ставится уже так: вы за ЦСКА или за «Спартак»? Мне отвратительна такая постановка вопроса.

7. Хронотоп события задается конфликтогеном - невозможность для травмированного вратаря участвовать в приближающемся европейском футбольном чемпионате по- ставила под вопрос результативность игры российской сборной без опытного игрока.

8. Масштаб определяется как важность спортивного события, а именно крупное соревнование - чемпионат Европы по футболу. Достаточно большой масштаб события придал драматизма восприятию травмы И. Акинфеева на внутрироссийском соревновании.

9. Ресурсы понимаются как обеспечение потребностей и достижение необходимого результата. Конфликт возникает тогда, когда борьба ведется за реализацию витальных, статусных или творческих потребностей, за восполнение недостатка дефицитного ресурса, на который претендуют обе стороны. В игровых видах спорта ресурс материальный, в футболе - это мяч; но настоящая борьба идет за получение соответствующего качеству игры финансирования. Другие ресурсы нематериальны, но тоже добываются в борьбе: радость индивидуального достижения (гола), счастье командной победы, международный престиж страны, которую представляет команда-победительница.

10. Интересы участников, распоряжающихся ресурсом или желающих им завладеть, связаны со стремлением к личному успеху и победе команды, что заставляет игроков идти напролом, как это представлено в рассматриваемом игровом эпизоде.

11. Ценности - это идеальные конструкты: идеологические, патриотические, эстетические и др. Их фундаментальное членение на «свои» и «чужие» обусловлено социальным инстинктом. Конфликт ценностей это оборотная сторона конфликта ресурсов. Непримиримость ценностных позиций - сильнейший конфликтоген, поэтому в лингвоконфликтологии он, как правило, находится в центре внимания.

В мире спорта пристрастность и склонность к культивированию отдельных ценностей наиболее ярко проявляется в феномене фанатства: не только болельщики разных команд, но и игроки и даже функционеры демонизируют соперников, всячески умаляют их. См., например, высказывание главного тренера «Спартака» о травме вратаря соперничающей команды «ЦСКА», поражающее отсутствием сочувствия: 
То, что вратарь сборной выбыл на полгода, это его проблемы. Что, медаль ему повесить? Не трогать теперь игроков сборной?

12. Нормы как деятельностные корреляты ценностей, регуляторы ценностно мотивированного поведения в спортивном конфликте имеют два измерения - техническое и содержательное (этическое): футболист $X$ правильно провел передачу - сработал технично; футболист Х правильно сделал, что извинился после инцидента - повел себя этично.

Нормативное измерение конфликта включает в себя минимум три слоя: наивноэтический, профессионально-этический и юридический (правовой).

13. Информационное воплощение, языковая материя текстов, код (стиль, дискурс, жанр) - это традиционные объекты лингвистики и, соответственно, лингвоконфликтологии.

Конфликт «Веллитон - Акинфеев» обсуждался спортивными руководителями, наблюдателями (в том числе бывшими спортсменами) и журналистами «на высоком градусе накала», эмоционально, с использованием бранной лексики. При этом оппонентам адресовались этические оценки - вплоть до намеков в речевом преступлении (в экстремизме); конфликт развертывался на грани лингвоправового. Так, в газете «Спорт-Экспресс» защитник «ЦСКА» В. Березуцкий (из команды потерпевшего) заявил:

Совершенно очевидно, что Веллитон сыграл очень некрасиво и грубо.

Тренер армейских вратарей, в прошлом знаменитый голкипер сборной СССР В. Чанов сформулировал свою оценку ситуации в онлайн-издании «Спорт сегодня»:

Веллитон совершил очередной хамский поступок. Подобное отношение к вратарям у этого футболиста проявляется регулярно, и все сходит с рук.

В интервью «Спорт-Экспрессу» генеральный директор «ЦСКА» Р. Бабаев высказался очень резко:

Веллитон - настоящий подонок. Он в который раз уже атакует исподтишка. Мы посмотрели повтор эпизода: Акинфеев был первый на мяче, так что любая борьба была бессмысленной. Но Вел- литон умышленно его ударил. Некоторые болельщики уже обещают устроить возмездие. Мы не сторонники таких акций, но, тем не менее, пусть теперь осторожнее по улицам ходит.

Отметим в этих высказываниях парадокс: негативная оценка поведения спортсмена как неэтичного воплощена в форме грубой (Чанов: очередной хамский поступок) и даже оскорбительной (Бабаев: Веллитон настоящчий подонок). Эти конфликтогены провоцируют эскалацию конфликта и его трансформацию из спортивного в коммуникативный, то есть такой, где нарушены речеповеденческие нормы.

В интервью изданию «Советский спорт» гендиректор «Спартака» и его главный тренер В. Карпин отреагировал так:

Роман Бабаев - официальное лицо клуба. После подобного заявления занимать такие должности, как гендиректор клуба, в футболе он не может. Это призыв к насилию. Будем подавать заявление в прокуратуру. Мы что, хотим вторую Манежную площадь получить?

Здесь один высокопоставленный спортивный функционер обвиняет другого в призыве к экстремистскому насилию, напоминая о Манежной площади в Москве, где 12 декабря 2010 г. произошел митинг памяти болельщика «Спартака» Е. Свиридова, убитого приезжими кавказцами.

Однако обвинение в экстремизме (ст. 282 УК РФ) было надуманным; нет также оснований для обвинения в угрозе жизни и здоровью (ст. 119 УК РФ). В таком случае говорят о ложном характере конфликта. С точки зрения лингвоконфликтологии имеются признаки, нарушающие этику коммуникации, и разрешать данный конфликт необходимо не на уровне права, а на уровне морали.

В ответ на уголовные обвинения на официальном сайте «ЦСКА» прозвучали ответные обвинения этического характера, они воспроизведены на портале «Вести.ру»:

ЦСКА крайне удивлен заявлением Валерия Карпина относительно высказывания генерального директора ЦСКА Романа Бабаева, касающегося грязного поступка игрока «Спартака» Веллитона против вратаря армейцев и сборной России Игоря Акинфеева. Узнав о реакции некоторых болельщи- 
ков на данный эпизод, Роман Юрьевич отметил, что «мы не сторонники таких акций». И Валерию Карпину, прежде чем делать подобные заявления, которые вполне можно расценить как провокацию, следовало бы более внимательно читать высказывания своих коллег.

Этот «обмен любезностями» рефлексивен и демонстрирует, как на базе деятельностных конфликтов в результате нарушения универсальных правил или локальных конвенций общения возникают коммуникативные конфликты.

\section{Выводы}

Лингвоконфликтология представляет собой прикладную (вузовскую) речеведческую дисциплину, направление коммуникативной лингвистики и раздел юрислингвистики. А потенциально - органичную часть конфликтологии, хотя на сегодняшний момент специалисты по лингвоконфликтологии не входят в Российскую ассоциацию конфликтологов и не участвуют в их мероприятиях [Конфликтология..., 2019].

Специфика конфликтов формулируется в ЛКЛ в нескольких ключевых терминах. Термин речевой конфликт обозначает форму протекания деятельностного конфликта, а термин коммуникативный конфликт - противоборство по поводу конвенций самой информации / коммуникации. Это различение принципиально: оно позволяет понять конфликтогенный потенциал любого параметра коммуникации и осознать его ценностно-нормативный характер, социокультурную значимость. В ряде ситуаций, прежде всего в массмедиа, эти два конфликта могут совмещаться.

Термин лингвоправовой конфликт как специфический объект ЛКЛ указывает на рассмотрение коммуникативного противоречия через правовую / юридическую призму субъектом-истцом (персонажем критического текста) или заявителем из надзорной инстанции (прокуратуры, ФАС, ЦИК, Роскомнадзора). С одной стороны, ЛПК - это самая острая форма словесного конфликта, то есть явление коммуникативной природы, с другой правонарушение, то есть феномен правовой природы. В преподавании будущим экспертам и в лингвоэкспертной практике ЛПК может быть назван рабочим термином речевое (язы- ковое) преступление. Это деликт, где нарушаются: 1) права личности на честь, достоинство, деловую репутацию, жизнь; 2) право социума на эффективное и законосообразное функционирование институтов, в том числе СМИ; 3) права государства на безопасность населения, соблюдение законности, конституционного строя.

Если задача курсов стилистики и риторики в школе и в вузе - сформировать у обучающихся осознание нормативности общения и словесного творчества, научить воспринимать языковые и жанрово-дискурсивные нормы как возможность эффективного выбора и как необходимость творческого («вкусового») самоограничения, то задача лингвоконфликтологии, на наш взгляд, отрефлексировать нормы высшего уровня, нормы этико-правовые. С одной стороны, литература, журналистика, сфера рекламы регулируются стихийно сложившимися «цеховыми» нормами, незнание которых или пренебрежение которыми не позволяет создать качественный текст. Наказанием здесь служит неполучение прагматического или эстетического результата, интереса, одобрения читателей, отклонение текста редактором или издателем. С другой стороны, они подчиняются требованиям государственных законов, нарушение которых (от правонарушения по ГК РФ до преступления по УК РФ) наказывается в диапазоне от штрафов до тюремного заключения. Лингвоконфликтология как прикладная наука помогает осознать комплексные регуляторы и критерии креатива - от стилистических до юридических, выявляет механизмы коммуникативных конфликтов, обнаруживает конфликтогенность самой лингвистической экспертизы и способствует профилактике речевых деликтов.

\section{СПИСОК ЛИТЕРАТУРЫ}

Анцупов А. Я., Шипилов А. И., 2000. Конфликтология. СПб. : Питер. 551 с.

Ворошилова М. Б., 2013. Юрислингвистика: судебная лингвистическая экспертиза, лингвоконфликтология, юридико-лингвистическая герменевтика // Политическая лингвистика. № 1 (43). С. 211-212.

Галяшина Е. И., 2017. Проблемы повышения эффективности и качества судебной лингвисти- 
ческой экспертизы // Вестник Московского университета МВД России. № 2. С. 34-36.

Голев Н. Д., 2003. Юрислингвистика: программа курса для студентов филологического факультета, обучающихся по дополнительной специализации «Лингвокриминалистика» // Юрислингвистика-4: юридико-лингвистические дисциплины на юридических, филологических и журналистских факультетах российских вузов : межвуз. сб. науч. ст. Барнаул : АГУ. С. 62-72.

Голев Н. Д., Обелюнас Н. В., 2014. Лингвоконфликтология // Эффективное общение (базовые компетенции) : слов.-справ. / под ред. А. П. Сковородникова. Изд. 2-е, перераб. и доп. Красноярск : Сиб. федер. ун-т. С. 279280. Систем. требования: РС не ниже класса Pentium I ; 128 MB RAM ; Windows 98/XP/7 ; Adobe Reader 8.0 и выше.

Декатова К. Лингвоконфликтология: правовые и педагогические аспекты. URL: http://lms.vspu. ru/courses/lingvokonfliktologiya-pravovyie-ipedagogicheskie-aspkektyi (дата обращения: 23.01.18).

Кара-Мурза Е. С., 2010а. Лингвоконфликтология как пропедевтический курс для лингвистовэкспертов // Русский язык: исторические судьбы и современность : тр. и материалы IV Междунар. конгр. исследователей рус. яз. (Москва, 20-23 марта 2010 г.). М. : МГУ. С. 755-756.

Кара-Мурза Е. С., 2010б. Лингвоправовой конфликт как объект исследования в линовоконфликтологии // Юрислингвистика-10: лингвоконфликтология и юриспруденция : межвуз. сб. науч. ст. Барнаул ; Кемерово : Изд-во Алт. ун-та. C. 114-123.

Кара-Мурза Е. С., 2011. Лингвоконфликтология: основные понятия и вузовские варианты // Журналистика и культура русской речи. № 2 (58) ; № 3 (59); № 4 (60).

Конфликтология XXI века. Пути и средства укрепления мира, 2019 : материалы III Санкт-Петербург. междунар. конгр. конфликтологов (Санкт-Петербург, 15-16 нояб. 2019 г.). СПб. : Фонд развития конфликтологии. $438 \mathrm{c}$.

Понятия чести, достоинства и деловой репутации. Спорные тексты СМИ и проблемы их анализа и оценки юристами и лингвистами, 2004 / под ред. А. К. Симонова, М. В. Горбаневского. Изд. 2-е, перераб. и доп. М. : Медея. $328 \mathrm{c}$.

Речевая конфликтология, 2008 : учеб. пособие / отв. ред. М. Я. Дымарский. СПб. : Изд-во РГПУ им. А.И. Герцена. 215 с.

Третьякова В. С., 2010. Конфликт в лингвистических категориях // Юрислингвистика-10: лингвокон- фликтология и юриспруденция : межвуз. сб. науч. ст. Барнаул ; Кемерово : Изд-во Алт. ун-та. C. 141-149.

Чернышова Т. В., 2017. Основы лингвоконфликтологии : учеб. пособие. Барнаул : Алт. гос. ун-т. 190 c. 1 электрон. опт. диск (DVD). Систем. требования: PC, Intel 1 ГГц ; 512 Мб оператив. памяти ; 30 Мб свобод. дискового пространства ; DVD-привод ; OC Windows 7 и выше, ПО для чтения pdf-файлов.

\section{REFERENCES}

Antsupov A.Ya., Shipilov A.I., 2000. Konfliktologiya [Conflictology]. Saint Petersburg, Piter Publ. $551 \mathrm{p}$.

Voroshilova M.B., 2013. Yurislingvistika: sudebnaya lingvisticheskaya ekspertiza, lingvokonfliktologiya, yuridiko-lingvisticheskaya germenevtika [Juridical Linguistics: Forensic Linguistic Expertise, LingoConflictology, Juridical-Linguistic Hermeneutics]. Politicheskaya lingvistika [Political Linguistics], no. 1 (43), pp. 211-212.

Galyashina E.I., 2017. Problemy povysheniya effektivnosti i kachestva sudebnoy lingvisticheskoy ekspertizy [On the Problems of Efficiency and Quality Enchartment of Forensic Linguistic Expertise]. Vestnik Moskovskogo universiteta MVD Rossii, no. 2, pp. 34-36.

Golev N.D., 2003. Yurislingvistika: programma kursa dlya studentov filologicheskogo fakulteta, obuchayushchikhsya po dopolnitelnoy spetsializatsii «Lingvokriminalistika» [Juridical Linguistics: Program of the Course for Students of the Philological Faculty Studying on the Additional Specialisation "Forensic Linguistics"]. Yurislingvistika-4: yuridikolingvisticheskie distsipliny na yuridicheskikh, filologicheskikh $i$ zhurnalistskikh fakultetakh rossiyskikh vuzov: mezhvuz. sb. nauch. st. [Juridical Linguistics-4: Legal and Linguistic Disciplines on Legal, Philological and Journalistic Faculties of Russian Universities. Interuniversity Collection of Scientific Articles]. Barnaul, AGU, pp. 62-72.

Golev N.D., Obelyunas N.V., 2014. Lingvokonfliktologiya [Linguoconflictology]. Skovorodnikov A.P., ed. Effektivnoe obshchenie (bazovye kompetentsii): slov.-sprav. [Effective Communication (Basic Competencies). Reference Dictionary]. Krasnoyarsk, Sibirskiy federalnyy universitet, pp. 279-280. System requirements: PC Pentium I or higher; $128 \mathrm{MB}$ RAM; Windows 98/XP/7; Adobe Reader V. 8.0 or higher. 
Dekatova K. Lingvokonfliktologiya: pravovye $i$ pedagogicheskie aspekty [Linguoconflictology: Legal and Pedagogical Aspects]. URL: http:// lms.vspu.ru/courses/lingvokonfliktologiyapravovyie-i-pedagogicheskie-aspkektyi/ (accessed 23 January 2018).

Kara-Murza E.S., 2010 a. Lingvokonfliktologiya kak propedevticheskiy kurs dlya lingvistovekspertov [Linguoconflictology as an Introductory Course for Linguists-Experts]. Russkiy yazyk: istoricheskie sudby $i$ sovremennost: tr. i materialy IV Mezhdunar. kongr. issledovateley rus. yaz. (Moskva, 2023 marta 2010 g.) [Russian Language: Historical Destinies and Modernity. $4^{\text {th }}$ International Congress of Russian Language Researchers. Works and Proceedings. Moscow, March 20 23, 2010)]. Moscow, MGU, pp. 755-756.

Kara-Murza E.S., 2010 b. Lingvopravovoy konflikt kak obyekt issledovaniya $\mathrm{v}$ linovokonfliktologii [Linguolegal Conflict as an Object of Study in Lingvoculturology]. Yurislingvistika-10: lingvokonfliktologiya i yurisprudentsiya: mezhvuz. sb. nauch. st. [Juridical Linguistics-10: Linguoconflictology and Jurisprudence. Interuniversity Collection of Scientific Articles]. Barnaul, Kemerovo, Izd-vo Altayskogo universiteta, pp. 114-123.

Kara-Murza E.S., 2011. Lingvokonfliktologiya: osnovnye ponyatiya i vuzovskie varianty [Linguoconflictology: Basic Concepts and Institutional Options]. Zhurnalistika i kultura russkoy rechi, no. 2 (58), no. 3 (59), no. 4 (60).

Konfliktologiya XXI veka. Puti i sredstva ukrepleniya mira: materialy III Sankt-Peterburg. mezhdunar. kongr. konfliktologov (Sankt-
Peterburg, 15-16 noyab. 2019 g.), 2019 [Conflictology of the $21^{\text {st }}$ Century. Ways and Means of Strengthening Peace: Proceedings of the $3^{\text {rd }}$ Saint Petersburg International Congress of Conflict Scientists (Saint Petersburg, November 15-16, 2019)]. Saint Petersburg, Fond razvitiya konfliktologii. $438 \mathrm{p}$.

Simonov A.K., Gorbanevskiy M.V., eds., 2004. Ponyatiya chesti, dostoinstva $i$ delovoy reputatsii. Spornye teksty SMI i problemy ikh analiza $i$ otsenki yuristami $i$ lingvistami [Concepts of Honor, Dignity and Business Reputation. Controversial Media Texts and Problems of Their Analysis and Evaluation by Lawyers and Linguists]. Moscow, Medeya Publ. $328 \mathrm{p}$.

Dymarskiy M.Ya., ed., 2008. Rechevaya konfliktologiya: ucheb. posobie [Speech Conflictology. Study Guide]. Saint Petersburg, Izd-vo RGPU im. A.I. Gertsena. 215 p.

Tretyakova V.S., 2010. Konflikt v lingvisticheskikh kategoriyakh [Conflict in Linguistic Categories]. Yurislingvistika-10: lingvokonfliktologiya $i$ yurisprudentsiya: mezhvuz. sb. nauch. st. [Juridical Linguistics-10: Linguoconflictology and Jurisprudence. Interuniversity Collection of Scientific Articles]. Barnaul, Kemerovo, Izd-vo Altayskogo universiteta, pp. 141-149.

Chernyshova T.V., 2017. Osnovy lingvokonfliktologii: ucheb. posobie [Fundamentals of Linguoconflictology. Study Guide]. Barnaul, Altayskiy gosudarstvennyy universitet. 190 p. 1 electronic optical disk (DVD). System requirements: PC, Intel $1 \mathrm{GHz} ; 512$ MB RAM; $30 \mathrm{MB}$ free disk space; DVD-drive; Windows 7 or higher, software for reading pdf files.

\section{Information About the Author}

Elena S. Kara-Murza, Candidate of Sciences (Philology), Associate Professor, Department of Stylistics of the Russian Language, Lomonosov Moscow State University, Mokhovaya St., 9, Bld. 1, 125009 Moscow, Russia, kara-murza-elena@yandex.ru, https://orcid.org/0000-0003-2628-0218

\section{Информация об авторе}

Елена Станиславовна Кара-Мурза, кандидат филологических наук, доцент кафедры стилистики русского языка, Московский государственный университет им. М.В. Ломоносова, ул. Моховая, 9, стр. 1, 125009 г. Москва, Россия, kara-murza-elena@yandex.ru, https://orcid.org/0000-0003-2628-0218 